\title{
ミドリイシ科ニオウミドリイシ属（新称）Isoporaの 分類および生態
}

\author{
深見裕伸 $^{1} \cdot$ 磯村尚子 $^{2 *}$ ・岩尾研二 ${ }^{3} \cdot$ 立川浩之 ${ }^{4}$ \\ 1 宮崎大学農学部海洋生物環境学科％ $889-2192$ 宮崎県宮崎市学園木花台西 1-1 \\ 2 沖縄工業高等専門学校生物資源工学科 ７905-2192 沖縄県名護市辺野古 905 \\ 3 阿嘉島臨海研究所 $\bar{T} 901-3311$ 沖縄県島尻郡座間味村字阿嘉 179 \\ ${ }^{4}$ 千葉県立中央博物館 ７260-8682 千葉県千葉市中央区青葉町 955-2
}

\begin{abstract}
要旨イシサンゴ目に属するミドリイシ科 Acroporidae は, これまでミドリイシ属Acropora, トゲミド リイシ属Anacropora, アナサンゴ属Astreopora, コモンサンゴ属 Montiporaの 4 属であるとされていた (例えば, Veron and Wallace 1984; 西平・Veron 1995; Veron 2000)。しかし, 2007 年, Wallace らは, 形態的・生態的特徴と分子データを基に，ミドリイシ属内の亜属の一つであったIsopora を属へと昇格 させた（Wallace et al. 2007）。しかしながら，日本国内においてこの事実が周知されておらず，Isopora の種が未だミドリイシ属のままの学名で用いられていることが多い。また, Isoporaには亜属の時代か ら和名が与えられていない。そこで, この属の周知を図るため, 属に昇格したIsoporaの和名をニオウ ミドリイシ属（新称）として提唱するとともに, 本属の特徵および種の解説を行う。本稿は Wallace et al.（2007）を主体に, 今回観察した日本産Isopora の標本の形態デー夕を新たに加えてまとめたものであ る。また，国際動物命名規約に則り，これまでIsoporaのタイプ種とされていた Astrea palifera Lamarck, 1816 が間違いであり，実際にはMadrepora labrosa Dana, 1846 であることが判明したため，それについ ても記述する。
\end{abstract}

キーワード イシサンゴ, ニオウミドリイシ属, 骨格形態, 和名, 亜属, 日本産標本, タイプ種

\section{緒言}

2013 年現在, イシサンゴ目 Scleractinia のミドリ イシ科 Acroporidae Verrill, 1902 には 5 つの属が含 まれている。それらは, ミドリイシ属Acropora Oken, 1815, トゲミドリイシ属 Anacropora Ridley, 1884, アナサンゴ属 Astreopora Blainville, 1830, ニ オウミドリイシ属（新称）Isopora Studer, 1878, コモンサンゴ属 Montipora Blainville, 1830 である。 しかしながら, Wallace et al. (2007) によって Isoporaが属に昇格される以前は 4 属とされ，ミドリ イシ属が 2 つ亜属を含んでいた（以降, 亜属を含 んでいた時の名前をミドリイシ属（広義）とする)。 すなわち, 一つの枝に単一の中軸サンゴ個体（axial

\section{*連絡著者}

E-mail: iso@okinawa-ct.ac.jp

担当編集者: 服田昌之 (生物分野) corallite）を持つミドリイシ亜属 subgenus Acropora と, 基本的に二つ以上の中軸個体を持つ subgenus Isopora（以降，带属として用いるときは Isopora（亜属）とし，属として用いるときはその ままIsopora と記述する) である (図 1 参照)。こ れら形態的な特徴以外にも, 前者が卵数個と精子か らなるバンドルを放出する生殖様式（Wallace 1985, 1999）であるのに対し，後者はプラヌラ幼生保育と いう生殖様式 (Kojis 1986a, b; Veron and Wallace 1984）であるという違いがある。両者ともに雌雄同 体である。特に，ミドリイシ科においてプラヌラ幼 生保育型は, Isopora だけである。ただし, 近年, 分 子系統解析の結果に基づき（Fukami et al. 2008）,

プラヌラ幼生保育型と考えられているアワサンゴ属 Alveopora Blainville, 1830 (ハマサンゴ科 Poritidae Gray, 1842）をミドリイシ科に含めるという傾向が 見られ (Dai and Horng 2009)，それにならえばミ ドリイシ科は放卵放精型の 4 属と幼生保育型の 2 属 


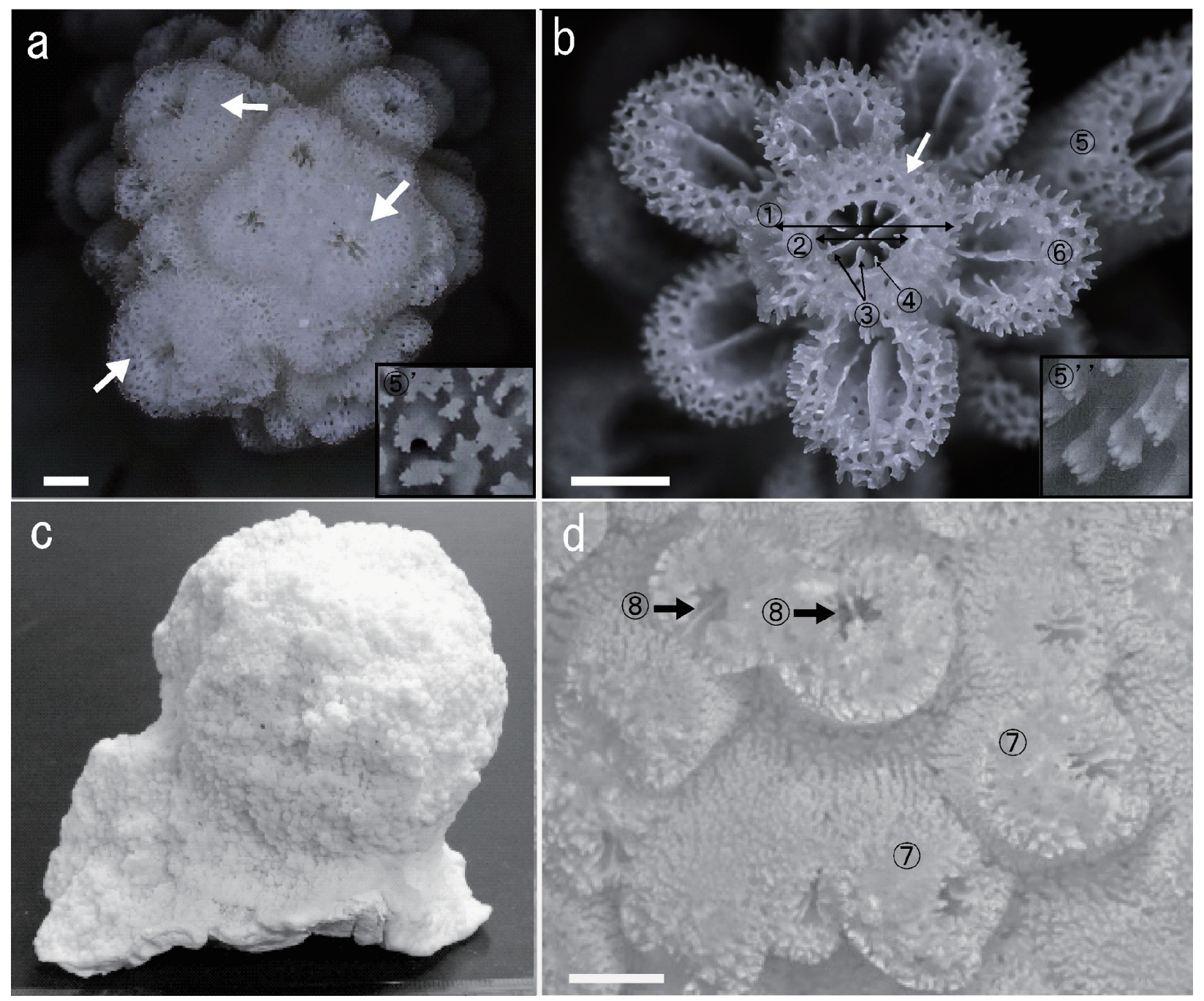

図 1 ニオウミドリイシ属およびミドリイシ属の基本骨格構造の特徴。a: フトエダミドリイシ Isopora brueggemanni, b: エンタクエダミドリイシ Acropora solitaryensis。c: 小笠原産のヒラニオウ ミドリイシI Isopora cuneata の群体形（幅 $9.9 \mathrm{~cm}$, 高さ $9.4 \mathrm{~cm}$ ), d: ニオウミドリイシ Isopora palifera の放射サンゴ個体の形状。太い白色矢印は中軸サンゴ個体を示す。(1)サンゴ個体径, (2)萊径, (3)一次 隔壁，(4)二次隔壁，(5)共骨，(5)ニオウミドリイシ属の共骨の棘，(5)”ミドリイシ属の共骨の棘，(6)放 射サンゴ個体。(7)外側が肥大した密着管状（ちくわの斜め切りに見える），8欠刻状開口（馬蹄形に 見える)。1枝あたりの中軸サンゴ個体の数は, ミドリイシ属では一つのみだが，ニオウミドリイシ 属では複数個（写真では 3 個）ある。スケールバーは $1 \mathrm{~mm}$

Fig. 1 Basic morphological characters of the genera Isopora and Acropora. a: Close-up of $I$. brueggemanni branch, b: Close-up of A. solitaryensis branch, c: Colony form of Isopora cuneata in Ogasawara $(9.9 \mathrm{~cm}$ width, $9.4 \mathrm{~cm}$ height), d: Close-up of $I$. palifera radial corallites. Arrows in bold show axial corallites. 1: Diameter of corallite, 2: Diameter of calice, 3: The primary septa, 4: The secondary septum, 5: Coenosteum, 5': Spinules of coenosteum of Isopora, 5": Spinules of coenosteum of Acropora, 6: Radial corallite, 7: Appressed tubular with the outer of the wall thickened, 8: Dimidiate openings. Note that Acropora has only a single axial corallite on the branch tip, whereas Isopora has three axial corallites. Scale bars show $1 \mathrm{~mm}$ 
の合計 6 属からなることになるが, 現在のところこ の扱いは一般的ではない。

Isoporaの分類学的な変遷についてはWallace et al.（2007）にまとめられている。それを元に, 以下 に簡潔にまとめた。元来, Isopora（亜属）はStuder （1878）によって提唱された。以降, Brook（1893） はミドリイシ属（広義）全体を体系立ててまとめ, Isopora（亜属）とは別に9つもの新しい带属を提 唱したが, Isopora（亜属）以外はその後受け入れ られず使用されていない。1980年代になり, Randall （1981）は群体形とサンゴ個体の形態的な特徵から Isopora（亜属）の属への昇格を提唱したものの, 数年後に発表された有藻性イシサンゴ類（zooxanthellate scleractinian corals）の一連のモノグラフ の中でミドリイシ科を扱ったVeron and Wallace （1984）においては亜属のままとされ, 以降, 亜属 として扱われてきた。この理由の主な原因は, 枝状 群体であるフトエダミドリイシ I. brueggemanniに ある。この種では中軸サンゴ個体が二つ以上という 形態的特徵が非常に曖昧（通常では中軸サンゴ個体 は一つであり，たまに中軸サンゴ個体を 2-3 個もっ た枝が見つかる程度）である。さらに，ミドリイシ 属と同様に放射サンゴ個体が明確であり，一見して ミドリイシ属と同定するのになんの差し障りもな い。Randall（1981）はフトエダミドリイシをIsopora (亜属) に含めていなかったために属への昇格を提 案したのだが, Veron and Wallace (1984) ではフ トエダミドリイシをIsopora（亜属）に含めたため に独立した属として扱うことに躊躇したのだろう。 また，個体間の骨格部分である共骨 (coenosteum) がIsoporaでは特徴的（メアンドロイド型になる細 分化した先端をもった棘 (elaborated meandroid coenosteal spinules）を持つ）であるとされている が (図 1a)，肉眼での見分けは非常に困難である。 ミドリイシ属も類似した棘を持つが先端があまり細 分化せずメアンドロイド型にもならない（図 1b)。 さらに, フトエダミドリイシは原記載に扮いて Isopora (亜属) であろうと考察されていた（Brook 1891）ものの, Veron and Wallace（1984）に至る までの期間は, ミドリイシ亜属として扱われてい た。同様に I. togianensis も, 当初ミドリイシ亜属 として記載されており（Wallace 1997），形態での 区別が困難だったことが伺える。

加えて, 亜属を表記する研究者は少なく, 例えば
その当時ニオウミドリイシは Acropora palifera と して様々な図鑑に紹介されており（西平・Veron 1995 など), Acropora (Isopora) palifera（亜属を 示す場合は属名の次にカッコに入れて表記する）の ように亜属を表記しなかったために, 亜属の存在が 忘れられていった感が否めない。しかしながら，近 年, 分子系統解析が発達し, Fukami et al. (2000) により再びIsopora（亜属）を属に昇格すべきであ るとの提唱がなされた。そして，分子と形態と生態 のデータを総合して, Wallace et al.（2007）におい てようやくIsopora（亜属）は属に昇格したのである。

本稿では, Wallace et al.（2007）に基づき本属の 特徵を紹介するとともに，著者らの調査によって明 らかとなった日本産のIsopora 3 種の形態的特徴や 生殖様式に関する知見を述べる。

標本番号と標本収納先

CMNH-ZG : 千葉県立中央博物館分館海の博物館 AMSL：阿嘉島臨海研究所

MUFS-C : 宮崎大学農学部海洋生物環境学科・深見 研究室

\section{分類}

ニオウミドリイシ属（新称）Genus Isopora Studer, 1878

科：ミドリイシ科

タイプ種: Madrepora labrosa Dana, 1846（junior synonym of Astrea palifera Lamarck, 1816)

タイプ産地：スールー海（The Sulu（Sooloo）Sea） (フイリピン)

注：Madreporaは記載時の属名。Brook（1893）に より M. labrosa は Astrea palifera Lamarck, 1816 の ジュニア・シノニム (新参異名) となり, その後属 名がAcropora，さらにIsoporaへと変更になった。 現在の Isopora palifera（Lamarck, 1816）の異名で ある。本属の和名は夕イプ種がニオウミドリイシで あることに由来する。また, タイプ種についての詳 細は後述の“タイプ種の解説”を参照。

特徵

以下,「群体形」,「骨格」,「生態」はWallace et al.（2007）を参照した。 
群体形：クサビ状 (cuneiform)（Wallace 1999, p.51, Fig. 28C 参照), 被覆状, 枝状。

骨格: 群体中に多数の中軸サンゴ個体か主要サンゴ 個体 (leading corallites: 群体の辺縁部や峰の上の 部分で中軸サンゴ個体のように見える大きめのサン ゴ個体）を持つ。もしくは枝あたり 2 つ以上の中軸 サンゴ個体を持つ傾向にある。また, 放射サンゴ個 体 (radial corallites) は多数見られる。共骨 (coenosteum）は，先端に緻密な飾りのあるメアンドロ イド型（蛇行したような形）をした棘で覆われてい る(図 1, 2 参照)。軸柱 (columellae) と横隔板 (dissepiments : 隔壁間や個体間をつなぐ仕切り板) を欠く。

生態：雌雄同体で, 卵母細胞と精巣は別々の隔膜で 発達し, 成熟した卵母細胞は隔膜糸が伸びた部分に 含有される。受精は体内で行われ，プラヌラ幼生と なり放出される。

分子系統関係：ミトコンドリア遺伝子の Cytocrome oxydase subunit b (cytb) (Fukami et al. 2000; Wallace et al. 2007) およびATP6 遺伝子（Fukami et al. 2000）と核遺伝子である Histon 2 遺伝子 (Wallace et al. 2007) により, 本属はミドリイシ属 を含むミドリイシ科の他属と遺伝的に明確に区別が 可能である。また, ミトコンドリア遺伝子の putative control region（調節領域に類似した領域）も ミドリイシ属と本属の間に大きな遺伝的違いを持つ ことが判明している（van Oppen et al. 2001）。遺 伝子バンク（例えば DDBJ: http://www.ddbj.nig. $\mathrm{ac} . \mathrm{p} /$ ）に登録されている DNA 塩基配列と解析方 法の簡便さを考慮すると, $c y t b$ 遺伝子が本属をミド リイシ属（もしくは他属）から区別するための分子 マーカーとして非常に有効である。種間の区別につ いては, Ayre et al. (1991) は, アロザイム分析に よってニオウミドリイシI. palifera とヒラニオウミ ドリイシ I. cuneataを区別できるとしているもの の, 同時に地域が異なると 2 種を区別できない場合 もあるとしていることから, 現状では分子マーカー による種間の区別は困難であるといえる。今後の解 析が待たれる。

化石記録：中期中新世から現世（Budd and Wallace 2008)

\section{有効種および和名}

現生種

Isopora brueggemanni (Brook, 1891) ${ }^{\text {注 } 1}$

フトエダミドリイシ

Isopora crateriformis (Gardiner, 1898)

オワンニオウミドリイシ注 2 (新称)

Isopora cuneata (Dana, 1846)

ヒラニオウミドリイシ

Isopora palifera (Lamarck, 1816)

ニオウミドリイシ

Isopora togianensis (Wallace, 1997)

トギアンニオウミドリイジ注 3 (新称)

注 1 : 一般的には, 大英博物館のミドリイシ類のカ タログとして出版された Brook（1893）が原記載と されているが, これに先立ち同じ著者が新種を速報 的に記載した Brook (1891) が本種の原記載である。 なお, Wallace (1999) では, p. 370 の本種の解説ペー ジでは原著者をBrook（1893）としているが，原記 載の一覧を示したp. 11 の表では Brook（1891）と 正しく表記している。

注 2：噴火口（crateriform）という意味の種小名の 通り, カップ状の群体形が本種の特徴である。

注 3 : トギアン諸島でのみ生息が確認されている。

化石種

Isopora curacaoensis Budd and Wallace, 2008 和名無し

Isopora ginsbergi Budd and Wallace, 2008 和名無し

上記 2 種ともにカリブ海のキュラソー島（Curaçao） にある新第三紀（約 2400 万年前～約 200 万年前） の石灰岩から採集（Budd and Wallace 2008）。

\section{本属の可能性がある種}

現在, ミドリイシ属とされている種の中にも本属 であると思われる種がある。例えば, Veron（2000） において枝状の群体形を持っており，一本の枝に中 軸サンゴ個体がいくつか見られると記載もしくはそ のような写真が掲載されているAcropora elizabethensis Veron, 2000, A. cylindrica Veron, 2000, A. maryae Veron, 2000 などは, 将来的に共骨の観 
察および生殖様式の調查, もしくは分子系統解析を 行うと興味深い結果が得られるかもしれない。

\section{種の特徵}

現在, 本属は 7 種（化石種 2 種を含む）からなる。 現生種 5 種の文献上に記載された特徵を表 1 にまと めた。用いた文献はそれぞれの種の原記載論文およ び詳しい記載のある Veron and Wallace (1984) と Wallace (1999) である。原記載の情報は太字で示し, 後者 2 者間で記載内容が異なる場合はそれらを併記 した。

結論から言うと, 現生種 5 種の区別は骨格形態に おいて十分可能であり, ミドリイシ属と比較すると 種同定は容易であると言える。その中でも，もっと も種の区別が難しいのが, ニオウミドリイシ $I$. palifera とヒラニオウミドリイシI. cuneataである。 基本的にヒラニオウミドリイシは和名からわかるよ うに被覆状という印象が強く，一方，二オウミドリ イシは太い枝を持つという印象がある。しかしなが ら, 表 1 によとめたように, この 2 種の群体形の種 内形態変異の幅が重なっており, 両種とも同じ様な 群体形になりうる。また, ヒラニオウミドリイシも 実際は垂直に太い板が立ち上がるようなクサビ状の 群体形が主体である（種小名の cuneataがクサビ状 という意味)。小笠原ではクサビ状まではいかない もののかなり盛り上がった群体形が見られるが（図 1c), 日本の他所ではそのような群体形を見ないた め, 被覆という印象が強くなったのかもしれない。 いずれにせよ，群体形のみでこの 2 種を区別するの は難しい。では何を見れば区別ができるのか。それ には，やはり骨格形質を見る必要がある。まず，放 射サンゴ個体については，ニオウミドリイシのほう がヒラニオウミドリイシより小さいとされているが (表 1), どの程度小さいのかどこにも記述されてい ないため, この差はそれほど役に立たない。一方, 中軸サンゴ個体については前者が 2.8-4.2 mm で後 者が 1.5-3.1 mm とされており（表 1)，大きめのサ ンゴ個体同士を比較しない限り区別は難しいが, 全 体として $3 \mathrm{~mm}$ 以上の中軸サンゴ個体が多ければニ オウミドリイシであると判断できるだろう。さて, 結論から言うと, この 2 種のもっとも大きな違い は, ニオウミドリイシの放射サンゴ個体の内側部分
が共骨に密着し, 反対に外側部分が肥大するため, “ちくわの斜め切り”のような形になっているのに 対して (図 $1 \mathrm{~d}(7)$ ), ヒラニオウミドリイシでは綺麗 な円錐形の管状をしていることである（図 2D 参 照)。同時に, ニオウミドリイシの放射サンゴ個体 は開口部に切れ达みが入っている（欠刻開口： dimidiate opening）ため“馬蹄形”に見えるのに 対し (図 $1 \mathrm{~d}(8)$ ), ヒラニオウミドリイシの円錐形の サンゴ個体の開口部は綺麗な円形である（図 $2 \mathrm{D}$ 参 照)。特に, ニオウミドリイシのホロタイプの写真 (Corallsphare.org 参照 http://www.corallosphere. $\mathrm{org} / \operatorname{taxon} / 761$ 注：2010 年 3 月 16 日更新版）を見 るとこのような特徴がよくわかる。

これら 2 種の日本で採集した標本の写真を図 2 に 示す。これら 2 種は熱帯・亜熱帯域で広く見られる が (Wallace 1999), 分布北限域の日本では, ニオ ウミドリイシが奄美以南（西平・Veron 1995）で あるのに対し，ヒラニオウミドリイシは和歌山県の 串本が北限であろう（野村 2009）。ただし, Veron （2000）においてヒラニオウミドリイシは千葉周辺 まで棲息していることになっているが, 著者が知り うる限りそのようなデータは無い。一方, 今回, 既 報に加えて, ニオウミドリイシはトカラ列島, ヒラ ニオウミドリイシは小笠原でも新たに生息が確認さ れた。表 2 には日本産の両種の形態的特徴を示して いる。今回, 日本産の標本の観察から, この 2 種間 では共骨の棘の構造が互いに異なっていることが分 かってきた。ニオウミドリイシでは, 共骨の棘の先 端が緻密な飾りを持っており明確に棘全体が蛇行 (ここでは分岐しているように見える)している（図 2A-2）のに対し，ヒラニオウミドリイシでは棘の 先に緻密な飾りがあまり発達せず蛇行も弱く（図 2D-2), ミドリイシ属のそれ（図 $1 \mathrm{~b}$ 参照）と類似 していた。この違いは採集した地域に限らず 2 種間 の違いとして見られた。ちなみに，フトエダミドリ イシはこれらの中間的な形態をした共骨の棘を持っ ていた（図 2G-2）。今後, この特徵を精査すれば, 2 種間, さらには隠蔽種との違いを見るための新た な良い形態指標になる可能性がある。

それぞれの種の形態を見てみると, 典型的なニオ ウミドリイシは, サンゴ個体がちくわの斜め切りの ようになっているのが生態でもよくわかるのだが (図 2B), 群体によっては, 大部分のサンゴ個体が, 分厚く短い円筒形の管状になっているものもおり 
表 1 これまでに報告されたニオウミドリイシ属の種の形態的特徵。太字は原記載の内容である。1: Veron and Wallace (1984), 2: Wallace (1999), 下線部：本研究による情報

Table 1 Summary of taxonomic characters of the genus Isopora in the references. Original descriptions of each species were shown in bold. 1: Veron and Wallace (1984), 2: Wallace (1999), Underline: This study

\begin{tabular}{|c|c|c|c|c|}
\hline 種 & $\begin{array}{l}\text { ニオウミドリイシ } \\
\text { Isopora palifera }\end{array}$ & $\begin{array}{l}\text { ヒラニオウミドリイシ } \\
\text { Isopora cuneata }\end{array}$ & $\begin{array}{l}\text { オワンニオウミドリイシ(新称) } \\
\text { Isopora crateriformis }\end{array}$ & $\begin{array}{l}\text { フトエダミドリイシ } \\
\text { Isopora brueggemanni }\end{array}$ \\
\hline 文献 & $\begin{array}{l}\text { Lamarck (1816) 原記載 } \\
\text { Veron and Wallace (1984), } \\
\text { Wallace (1999) }\end{array}$ & $\begin{array}{l}\text { Dana (1846) 原記載 } \\
\text { Veron and Wallace (1984), } \\
\text { Wallace (1999) }\end{array}$ & $\begin{array}{l}\text { Gardiner (1898) 原記載 } \\
\text { Wallace (1999) }\end{array}$ & $\begin{array}{l}\text { Brook (1893) 原記載 } \\
\text { Veron and Wallace (1984), Wallace } \\
\text { (1999) }\end{array}$ \\
\hline 群体形 & $\begin{array}{l}\text { 球形に近い、もしくは凸状で } \\
\text { 群体表面には乳頭状突起も } \\
\text { しくは粒状の起がある。 } \\
\text { 被覆状、クサビ状、柱状のプ } \\
\text { レート、筒形状の太い枝など } \\
\text { 多様。枝の太さは15-150mm } \\
\text { で長さ200mm程度。 }\end{array}$ & $\begin{array}{l}\text { 被戛状で、数個の垂直に伸 } \\
\text { び出した広いプレートもしく } \\
\text { はクサビ状の突出部 (幅5 } \\
\text {-7.5cm)を持つ。 } \\
\text { 12-200mmの長さで0.5- } \\
\text { 3cmの厚さを持つクサビ状の } \\
\text { プレートもしく太い枝を持 } \\
\text { つ。部分的に被覆状になる。 }\end{array}$ & $\begin{array}{l}\text { 8-10cmの円形のカップ状。 } \\
\text { 深さ1.5cm。辺緑部の厚さは } \\
\text { 約 } 3 \mathrm{~mm} \text { 。中軸サンゴ個体は } \\
\text { 不明瞭。 } \\
\text { 円形で被覆状。80cm程度ま } \\
\text { で成長。中軸サンゴ個体はほ } \\
\text { ぼ認識できない。 }\end{array}$ & $\begin{array}{l}\text { 樹枝状であまり枝分かれしない。2- } \\
3 \mathrm{~cm} \text { のさ。長い枝は約15cm長で } \\
\text { 1.5cmの太さ。先端で分岐した枝は } 2 \\
\text {-3cmで1-1.5cmの太さ。 } \\
\text { 枝は6-18mm } 1 \text { (1.5-4cm) }{ }^{2} \text { のさで } \\
\text { 約8cmの長さ。基本的に中軸サンゴ個体 } \\
\text { は1個だが、2-3個持つものがある。 }\end{array}$ \\
\hline 中軸サンゴ個体 & $\begin{array}{l}\text { 枝やプレートの先端部分で顕 } \\
\text { 著。多く見られる。放射サンゴ } \\
\text { 個体よりわずかに大きい }\end{array}$ & 不明瞭 & $\begin{array}{l}\text { 不明瞭。稀に峰の先端部で認 } \\
\text { 識出来る程度。 }\end{array}$ & $\begin{array}{l}\text { 大きさの変異が大きい。非常に苏壁 } \\
\text { が厚い。あまり突出しないが、たまに } \\
\text { 2-3mm程度突出する。 }\end{array}$ \\
\hline 外径 & 外径: $2.8-4.2 \mathrm{~mm}$ & $1.5-3.1 \mathrm{~mm}$ & $1.5-2.2 \mathrm{~mm}$ & $\begin{array}{l}\text { 4-6mm } \\
2.9-4.5 \mathrm{~mm}^{1}(9 \mathrm{~mm} \text { まで })^{2}\end{array}$ \\
\hline 内径 & 内径: $0.7-1.4 \mathrm{~mm}$ & $0.5-1.0 \mathrm{~mm}$ & $0.5-0.8 \mathrm{~mm}$ & $1.0-1.6 \mathrm{~mm}^{1}(0.7-1.4 \mathrm{~mm})^{2}$ \\
\hline 隔壁 & & & & $\begin{array}{l}\text { 星型に見える。 } \\
\text { 三次隔壁が時々見られる。板状。 }\end{array}$ \\
\hline 一次 & 莢の半径と同じ大きさ & 萊の半径の2/3末満 & 萊の半径の1/3未満 & $\begin{array}{l}\text { よく発達 } \\
\text { 萊の半径の3/4末満 }\end{array}$ \\
\hline 二次 & 萊の半径の1/3未満 & 萊の半径の1/3未満 & $\begin{array}{l}\text { 無し、もしくは萊の半径の1/4 } \\
\text { 未満 }\end{array}$ & $\begin{array}{l}\text { あまり発達しない } \\
\text { 莢の半径の1/3未満 }\end{array}$ \\
\hline 放射サンゴ個体 & $\begin{array}{l}\text { 短くて太い円筒形。 } \\
\text { 長さ1-5mm程度で密着管 } \\
\text { 状。萊壁の外側が肥大。欠刻 } \\
\text { 状の開口部を持つ。 } \\
\text { サンゴ個体はちくわの斜め切 } \\
\text { 以のように見え、開口部は馬 } \\
\text { 蹄形に見える。 }\end{array}$ & $\begin{array}{l}\text { 密集しており、大きさがほほ } \\
\text { 揃っている。頑丈な管状 } \\
\text { で、長さ2.1ー3.2mm。 } \\
\text { 管状で円錐形。密着している } \\
\text { ものもある。 }\end{array}$ & $\begin{array}{l}\text { 管状もしくは密着管状で、2 } \\
\text {-3mmの長さ。1cmあたり7 } \\
\text { 個程度見られる。 } \\
\text { 円錐状もしくは密着円錐状 }\end{array}$ & $\begin{array}{l}\text { 大きさが不揃い。短くて厚い管状。一 } \\
\text { 部のサンゴ個体の外側が突出する。 } \\
\text { 長さ2-5mm。 } \\
\text { 密着管状もしくは円錐形。開口部は円 } \\
\text { 形。ほぼ同じ大きさ。 }\end{array}$ \\
\hline 外径 & & $\begin{array}{l}1.6 \mathrm{~mm} \\
1.5-3.1 \mathrm{~mm}\end{array}$ & $\begin{array}{l}1 \mathrm{~mm} \\
1.5-2.2 \mathrm{~mm}\end{array}$ & $2.5 \mathrm{~mm}$ \\
\hline 内径 & & $0.5-1.0 \mathrm{~mm}$ & $\begin{array}{l}0.4-0.5 \mathrm{~mm} \\
0.5-0.8 \mathrm{~mm}\end{array}$ & \\
\hline 隔壁 & & $\begin{array}{l}\text { 板状もしくは棘状で顆粒があ } \\
\text { る。 }\end{array}$ & 不明瞭 & $\begin{array}{l}\text { 星型に見える。 } \\
\text { 完全な2サイクル。板状。 }\end{array}$ \\
\hline 一次 & 萊の半径と同じ大きさ & 萊の半径の1/3未満 & 萊の半径の1/3未満 & $\begin{array}{l}\text { よく発達。 } \\
\text { 萊の半径の2/3未満(1/2-3/4末満) }\end{array}$ \\
\hline 二次 & 萊の半径の1/3未満 & 萊の半径の1/4未満 & 萊の半径の1/4末満 & $\begin{array}{l}\text { あまり発達しない。 } \\
\text { 萊の半径の1/4未満(無しもしくは1/2 } \\
\text {.未渾) }\end{array}$ \\
\hline 共骨 & $\begin{array}{l}\text { メアンドロイド型の細分先端を } \\
\text { 持つ䊂が密集 }\end{array}$ & $\begin{array}{l}\text { メアンドロイド型の細分先端を } \\
\text { 持つ棘が密集 }\end{array}$ & 細分先端を持つ棘が密集 & $\begin{array}{l}\text { メアンドロイド型の細分先端を持つ棘が } \\
\text { 密集 }\end{array}$ \\
\hline その他 & $\begin{array}{l}\text { 放射サンゴ個体の萊部分が花 } \\
\text { が咲いたような形態になること } \\
\text { がある。 }\end{array}$ & & $\begin{array}{l}\text { 群体の側面にできる石灰質 } \\
\text { の膜(エビセカ)が発達しシ } \\
\text { ワ状に見える。 } \\
\text { コモンサンゴのように微針 } \\
\text { (papillae)に似た構造を持つ } \\
\text { 群体もある。 }\end{array}$ & \\
\hline
\end{tabular}

（図 2A），群体によって見た目がかなり異なる。ヒ ラニオウミドリイシについては, 西平・Veron （1995）に揭載されているヒラニオウミドリイシ（p. 89）の上段の生態写真が, この種のサンゴ個体の特
徵（いわゆる，サンゴ個体が円錐形管状で口部が円 形）をよく表している。この生態写真は本研究で図 2D に掲載した生態および骨格標本の特徵, さらに は観察した小笠原の骨格標本（7 標本）とも良く一 

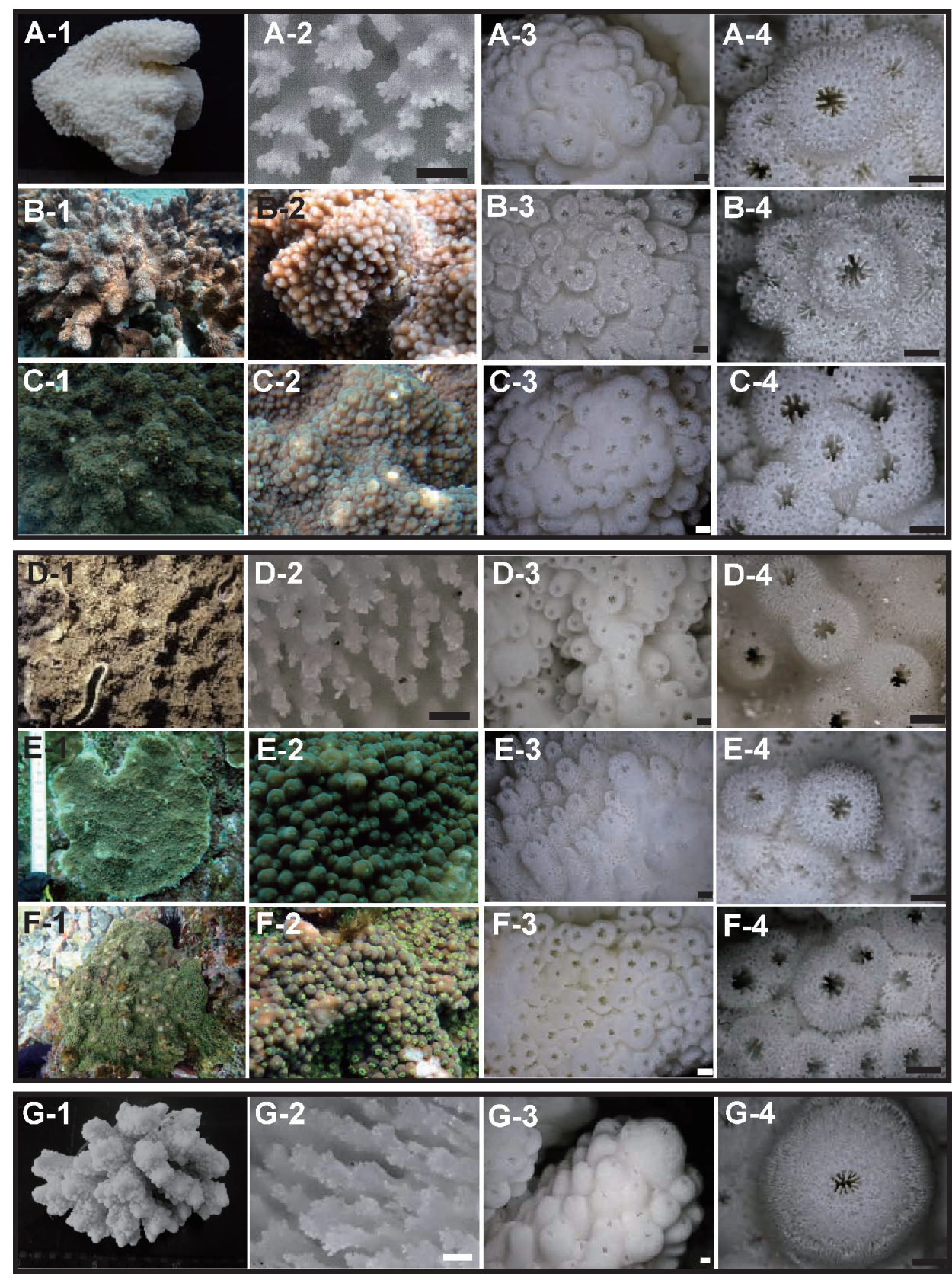

図 2 日本産ニオウミドリイシ属 3 種の形態。ニオウミドリイシ (A-C)，ヒラニオウミドリイシ（D-F），フトエダ ミドリイシ $(\mathrm{G})$ 。 1: 生時の群体（B-1, C-1, D-1, E-1, F-1）もしくは骨格標本（A-1, G-1），2: 生時の群体の拡大（B-2， C-2, E-2, F-2) もしくは共骨の構造 (A-2, D-2, G-2 バーは $100 \mu \mathrm{m})$, 3: 骨格標本の拡大（スケールバーは全て $1 \mathrm{~mm})$ ，4: 中軸サンゴ個体もしくは主要サンゴ個体の拡大（スケールバーは全て $1 \mathrm{~mm}$ )。採集場所と標本番号は以 下のとおり。A: 沖縄県阿嘉島（AMSL 0359），B: 沖縄島（MUFS-C 65）， C: 鹿児島県卜カラ列島（MUFS-C 71）D: 沖縄県屋嘉比島 (AMSL 0544)，E: 鹿児島県卜カラ列島（MUFS-C 72），F：宮崎県串間市 (MUFS-C 70)， G: 小笠 原父島（CMNH-ZG 06412）

Fig. 2 Morphologies of three species in the genus Isopora collected in Japan. Isopora palifera (A-C), I. cuneata (DF), I. brueggemanni (G). 1: Live colonies (B-1, C-1, D-1, E-1, F-1) and skeletal specimens (A-1, G-1), 2: Close up of live colonies (B-2, C-2, E-2, F-2) and spinules of coenosteum (A-2, D-2, G-2 Scale bars show $100 \mu \mathrm{m})$, 3: Close-up of skeletons (Scale bars show $1 \mathrm{~mm}$ ), 4: Close-up of axial corallites or leading corallites (Scale bars show $1 \mathrm{~mm}$ ). Collection sites and sample numbers are A: Aka Isl., Okinawa (AMSL 0359), B: Okinawa Island, Okinawa (MUFS-C 65), C: Tokara Isls., Kagoshima (MUFS-C 71), D: Yakabi Isl., Okinawa (AMSL 0544), E: Tokara Isls., Kagoshima (MUFS-C 72), F: Kushima, Miyazaki (MUFS-C 70), G: Chichijima, Ogasawara Isls (CMNH-ZG 06412) 


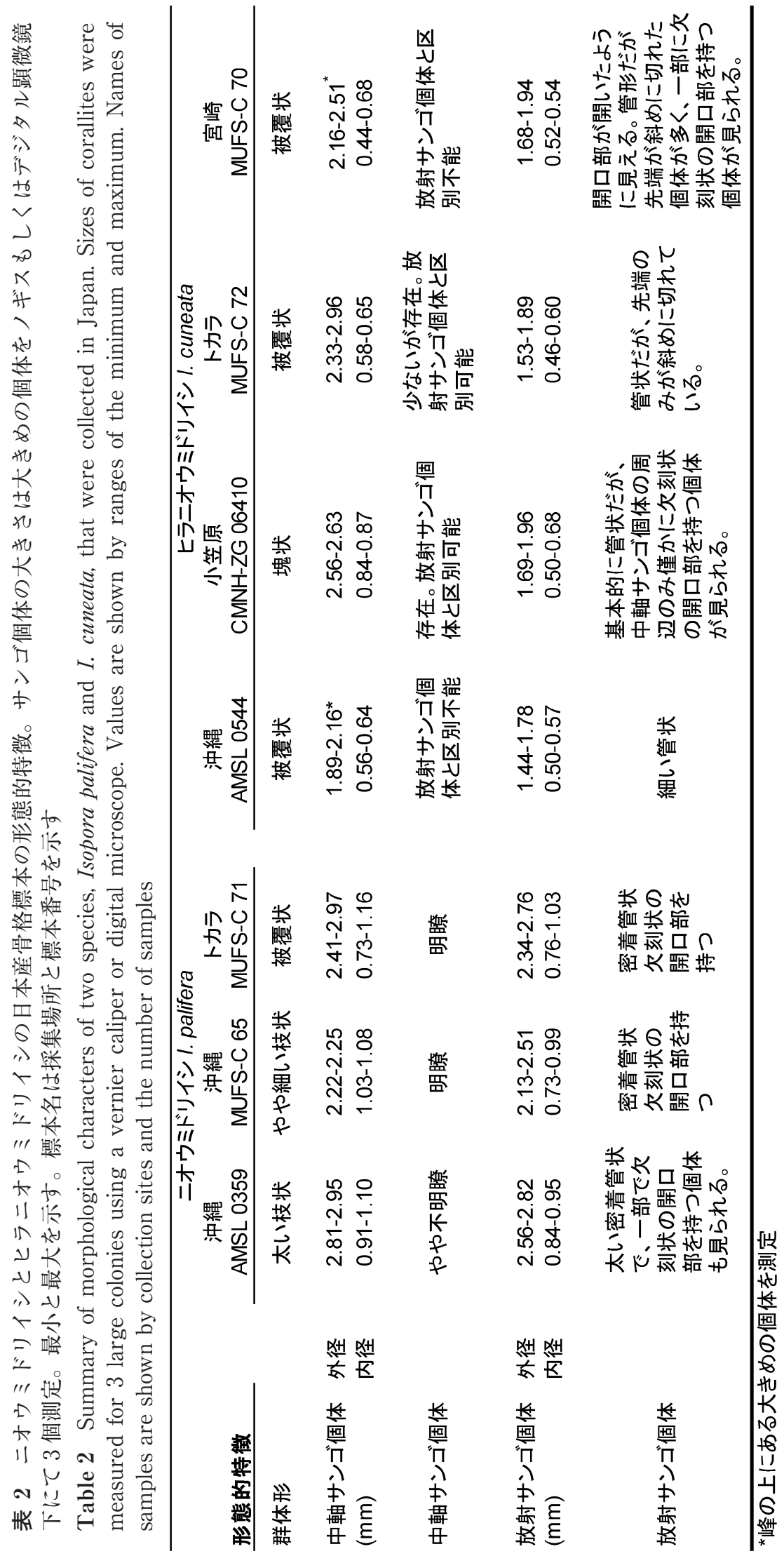


致している。ただし, 本研究で用いたトカラ列島お よび宮崎産のものは, 典型的な沖縄産, 小笠原産の ものに比べ，それぞれ放射サンゴ個体の形がわずか に異なっていた（表 2)。今後, 分子系統解析など さらなる解析が必要だろう。それによって, これら 標本の中から日本固有の種が見つかるかもしれない。

また，興味深いことに, Veron and Wallace (1984) では，ニオウミドリイシの一形態変異がフトエダミ ドリイシ I. brueggemanni と類似するとある（Veron and Wallace 1984 p.154 Fig. 356)。Wallace (1999) にも同様の写真が掲載されている（Wallace 1999 color plate 24 右上)。しかしながら, フトエダミド リイシについては, 萊壁が分厚い大きな中軸サンゴ 個体を持つ樹枝状群体という特徵から, 基本的に日 本ではミドリイシ属を含め他に類似する種がいない ため，現場でも同定が非常に容易である。さらに， 中軸サンゴ個体が枝あたり基本一つしかないことも 良い特徴となる。このフトエダミドリイシはこれま で日本では沖縄県でのみの報告であったが（Wallace 1999; Veron 2000), 1991 年に小笠原諸島父島にて 採集された標本を観察したところ，1群体が本種で あることが判明したため, ここに報告する（図 $2 \mathrm{G})$ 。

一方, 日本では報告されていないが，トギアンニ オウミドリイシ I. togianensis の太い枝の群体がフ トエダミドリイシとも類似すると記載されている (Wallace 1997)。ただし，トギアンニオウミドリイ シは共骨上にフトエダミドリイシには見られない粒 状突起（tuberculae: 疮状の骨格構造）が発達する ため（Wallace 1997 p.44, Fig. 13C), 骨格を顕微鏡 下で観察すれば容易に区別可能である。

最後に，これも日本では報告されていないが，オ ワンニオウミドリイシI. crateriformis についてで ある。この種は大きさ $10 \mathrm{~cm}$ 程度の小型の 1 群体を 基に記載されており（Gardiner 1898），しかもサン ゴ個体の特徵がヒラニオウミドリイシと極めて類似 している（Wallace 1999; 表 1）ことを考慮すると, ヒラニオウミドリイシの幼群体である可能性も考え られる。しかしながら, Gardiner（1898）の記載で は本種はカップ状で被覆しないという特徵があり, 同様の形質を持った大きな群体が Wallace（1999） の color plate 24 にも掲載されているため, この群 体形がこの種を特徵づける形質であるとするなら ば，被覆状もしくはクサビ状の板を持つヒラニオウ
ミドリイシと区別できるだろう。ただし，Wallace （1999）は本種が被覆すると記載しており, 群体形 が円形であることが大きな違いであるとしている。 以上のことを考慮して，日本産のヒラニオウミドリ イシを見てみると，群体形が円形に近いものがみら れる（例えば，西平・Veron（1995）など）が，す べて被覆状である。現状では, どちらかといえばヒ ラニオウミドリイシだろうと考えられるものの, 群 体形と種の対応については今後さらに精査する必要 があり，それによっては，本種が日本でも確認され る可能性がある。

\section{生態}

ニオウミドリイシ，ヒラニオウミドリイシおよび フトエダミドリイシは, 褐虫藻を持たない, 長径 1-2 mm の比較的大きなプラヌラ幼生を放出する (Atoda 1951; Kojis 1986a; 図 3)。アロザイムや遺伝 子を用いた集団解析から，ニオウミドリイシとヒラ ニオウミドリイシは他家受精によりプラヌラ幼生を 生産することが報告されている（Benzie et al. 1995; Ayre and Hughes 2000; Ayre and Miller 2006)。 一方, フトエダミドリイシでは, 組織学的観察から プラヌラ幼生生産の一部は自家受精によることが示 されている (Okubo et al. 2007)。しかし，これら 3 種はすべて雌雄同体で体内受精を行なうため, い ずれの種についてもプラヌラ幼生生産は他家受精と 自家受精両方によって行なわれている可能性がある。

プラヌラ幼生放出時期は種や地域で異なってい る。ニオウミドリイシは, オーストラリアの Heron Island では 1-3 月に, Lizard Island では 4, 8 月お よび 11 月終わりから 12 月初めに, 沖縄では著者ら が観察した限り少なくとも5月以降にプラヌラ幼生 が放出される (Kojis 1986a, b; 磯村ら未発表)。一 方ヒラニオウミドリイシは，オーストラリアの Heron Island では月齢に関係なく 9-12月にプラヌ ラ幼生が放出される（Kojis 1986a）。また，フィリ ピンのヒラニオウミドリイシは日没後にプラヌラ放 出することが報告されている（Villanueva et al. 2011)。ただし，日本におけるヒラニオウミドリイ シの生殖およびプラヌラ幼生放出に関しての詳細は 不明であり, 今後調查が必要である。さらに, フト エダミドリイシは，パラオでは月齢に関係なく一年 

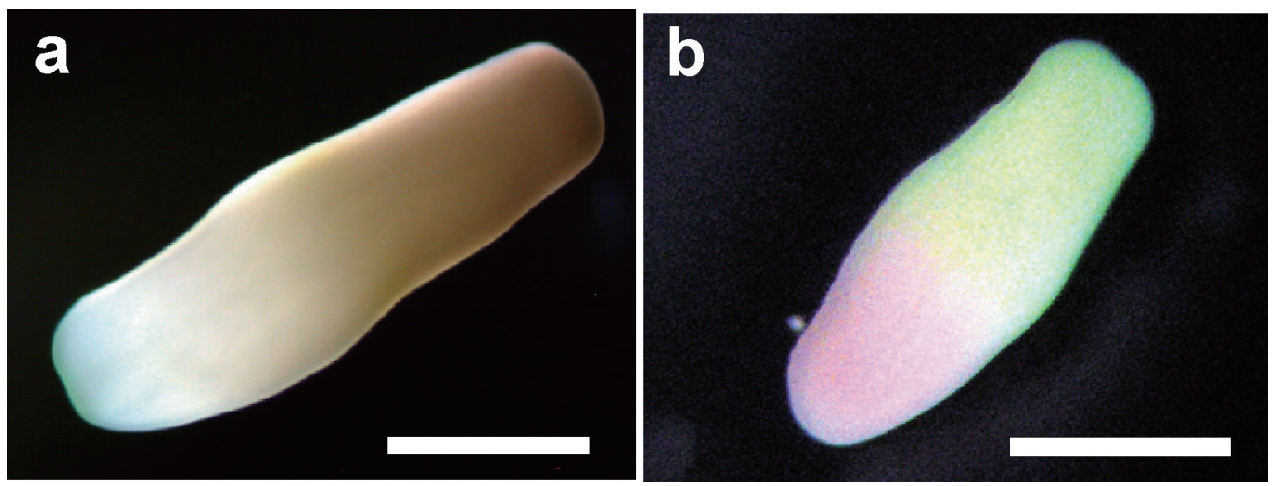

図 3 日本産ニオウミドリイシ属のプラヌラ幼生。a. ニオウミドリイシ，b. フトエダミドリイシ。 スケールバーは全て $1 \mathrm{~mm}$

Fig. 3 Planula larvae of Isopora collected in Japan. a. I. palifera, b. I. brueggemanni. Scale bars show $1 \mathrm{~mm}$

を通して (Atoda 1951)，沖縄では月齢に関係なく 9-12 月および 2 月 (Okubo et al. 2007) に放出が確 認されている。

3 種とも，比較的波あたりが強く，浅い場所に生

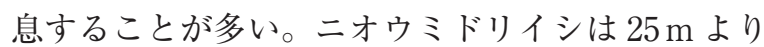
浅い場所に生息しており（Kojis 1986b），5mより 浅い場所で生息数が多く, 媣くなるにつれて生息数 が減っていくことが報告されている（Kojis 1986a, b)。ヒラニオウイドリイシはニオウイドリイシに 比べより波あたりの強い場所（礁縁部）に生息する 傾向がある (Ayre et al. 1991)。オーストラリアの Heron Island でも礁原では両種ともに見られるも ののニオウミドリイシの割合が多く，礁縁部ではヒ ラニオウミドリイシだけが確認されている（Kojis 1986a)。また, フトエダミドリイシも, 礁原や礁池 内に多く分布している (Atoda 1951)。

ニオウミドリイシとヒラニオウミドリイシは，太 い枝や被覆状の形態を持つことにより，波浪による 断片化は稀である。また破片が生じたとしても， 1-2ケ月で死亡するため, これら 2 種の生活史にお いて破片化による加入は重要な役割を担っていない (Kojis 1986a)。一方フトエダミドリイシは, 群体 近くの基盤上に多くの折れた枝が存在し，その一部 は定着して生き続けることができる（廣瀬他 2010）。 また, 地域集団は集団間で遺伝的に分化しているこ とが示された（磯村 未発表）。このことから，フト エダミドリイシにおいて破片化が集団の維持に重要 な役割を果たしていると考えることができる。

以上のように，ニオウミドリイシ，ヒラニオウミ
ドリイシ，フトエダミドリイシは，同じニオウミド リイシ属であっても生態的特徵は種間で異なってい る。今後は，各種についてはもちろんであるが，種 内でも生息地域や環境が異なる集団や群体の生態的 特徵を詳細に調査する必要があるだろう。

\section{タイプ種の解説}

今回, タイプ種の間違いが明らかになったため, ここに説明する。Veron and Wallace（1984）は Isopora（亜属）とそのタイプ種を以下のように定 義した。

“Subgenus Isopora Studer, 1878

Type species Acropora palifera (Dana, 1846) (subsequent designation, this study)"

この経緯は, Wallace et al.（2007）および Corallo sphere.org (http://www.corallosphere.org/taxon/ 7612010 年 3 月 16 日更新版）にある。

しかしながら，ここに 3 つの問題点が存在する。 まず, Acropora paliferaの著者と記載年が間違って いる。正しくは Acropora palifera (Lamarck, 1816) である。2 番目に, 指定されたタイプ種が, 設立時 と違う属名との組み合わせになっている。Lamarck (1816）は Astrea palifera として記載しているため, 正しくは Astrea palifera Lamarck, 1816 である。た だし，これら 2 つは間違いではあるが，国際動物命 
名規約上は違反ではない（動物命名法国際審議会 (2000）の条 67.7 および钓告 67B を参照)。現在,

Wallace et al. (1997) や Corallsphare.org では, こ れらが修正されて Astrea palifera Lamarck, 1816 と されているのだが, 実は, これもまだ間違いである ことが判明した。

それが, 3 番目の問題点につながる。国際動物命 名規約では,「名義種は, 設立時に含められた名義 種である場合に限り, 名義属もしくは名義亜属の夕 イプ種として固定するのに適任である」(条 67.2) とある。つまりIsopora（亜属）の設立時に含まれ た種をタイプ種として用いなければならないという ことである。Studer（1878）が Isopora（亜属）の 設立時に含めたのは Madrepora labrosa Dana, 1846 と Madrepora securis Dana, 1846 の 2 種のみであ り, palifera という名義種は含まれていないので, Veron and Wallace（1984）はこのルールを無視し たことになる。ただし，条 69.2.2に「設立時に含ま れていなかった名義種をタイプ種として指定する場 合・・・は, それと同時にその名義種を設立時に含 まれた名義種・・・のうちただ 1 種の異名リスト中 に置く場合に限り，その行為によって，その（設立 時に含まれた）名義種を当該の名義属もしくは名義 亜属のタイプ種として固定したことになる」とあ る。これをIsopora（亜属）に当てはめてみると, palifera タイプ種と指定する場合は，まず，設立 時に含まれた名義種である Madrepora labrosaか Madrepora securis のどちらかを異名リストに含め ている必要があるということであり, これは実際 Veron and Wallace (1984) がAcropora (Isopora) paliferaの異名リストにMadrepora labrosa Dana, 1846 を含めている。ただし, 条 69.2.2 の最後の 1 文（下線部）に書いてあるように, paliferaをタイ プ種と指定する行為は, paliferaの異名リストにあ る設立時に含まれた名義種を自動的にタイプ種に固 定することになる。つまり, この場合, 結果的に Madrepora labrosa Dana, 1846 がタイプ種として固 定されたことになるのである。よって, Isopora（亜 属), 現在の Isopora のタイプ種は Madrepora labrosa Dana, 1846 となるのである。

\section{Type species of the genus Isopora}

Veron and Wallace (1984) newly designated the type species of the subgenus Isopora Studer, 1878 as Acropora palifera (Dana, 1846) because Studer (1878) did not design the type species when he first proposed this subgenus. However, there were a few mistakes in this designation based on International Code of Zoological Nomenclature (ICZN 1999). First, name of the designated type species, Acropora palifera (Dana, 1846) should be Astrea palifera Lamarck, 1816. In Wallace et al. (1997) and Corallosphere.org (http://www.corallosphere.org/ taxon/761, revised Mar 16, 2010), it was already corrected. Nevertheless, we found that it is not correct yet.

The International Code of Zoological Nomenclature (Art. 69.22) describes as follows;

“69.2.2. If an author designates as type species a nominal species that was not originally included (or accepts another's such designation) and if, but only if, at the same time he or she places that nominal species in synonymy with one and only one of the originally included species (as defined in Article 67.2), that act constitutes fixation of the latter species as type species of the nominal genus or subgenus."

When Studer (1878) first proposed the subgenus Isopora, only two species, Madrepora labrosa Dana, 1846 and Madrepora securis Dana, 1846 were included. But Veron and Wallace (1984) did not select either species name used in Studer (1878), and newly designated the type species as Acropora palifera (Dana, 1846) although A. palifera contains $M$. labrosa as the junior synonym. As the result, based on the International Code of Zoological Nomenclature (Art. 69.2.2., see underline above), new designation of $A$. palifera as the type species by Veron and Wallace (1984) led to the designation of $M$. labrosa as the type species of the subgenus Isopora automatically. At present that the subge- 
nus Isopora was elevated to genus, true type species of the genus Isopora is M. laborosa Dana, 1846.

\section{謝辞}

東邦大学理学部の西川輝昭教授, 北海道大学理学 部の柁原 宏准教授, 国立科学博物館の長谷川和範 研究主幹, 千葉県立中央博物館の駒井智幸主任上席 研究員には, 命名規約上の検討に関して, さまざま なご教示をいただいた。投稿に際し, 查読者の方々 からは本稿への有益なコメントを頂いた。以上の 方々に厚く御礼申し上げる。

\section{参考文献}

Atoda K (1951) The larva and postlarval development of the reef-building corals. III. Acropora brueggemanni (Brook). J Morph 89: 1-16

Ayre DJ, Hughes TP (2000) Genotypic diversity and gene flow in brooding and spawning corals along the Great Barrier Reef, Australia. Evolution 54: 1590-1605

Ayre DJ, Miller KJ (2006) Random mating in the brooding coral Acropora palifera. Mar Ecol Prog Ser 307: 155-160

Ayre DJ, Veron JEN, Dufty SL (1991) The corals Acropora palifera and Acropora cuneata are genetically and ecologically distinct. Coral Reefs 10: $13-18$

Benzie JAH, Haskell A, Lehman H (1995) Variation in the genetic composition of coral (Pocillopora damicornis and Acropora palifera) populations from different reef habitats. Mar Biol 121: 731739

Brook G (1891) Descriptions of new species of Madrepora in the collections of the British Museum. Ann Mag Nat Hist 8: 458-465

Brook G (1893) The genus Madrepora. Catalogue of Madreporarian corals in the British Museum of Natural History 1: 1-212

Budd AF, Wallace CC (2008) First record of the
Indo-Pacific reef coral genus Isopora in the Caribbean region: two new species from the Neogene of Curaçao, Netherlands Antilles. Palaeontology 51: 1387-1401

Dai C-F, Horng S (2009) Scleractinia fauna of Taiwan. I The Complex Group. Taipei: National Taiwan University

Dana JD (1846) Zoophytes. United States Exploring Expedition. 7: 740pp; Atlas, 61pls

動物命名法国際審議会（2000）国際動物命名規約第 4 版日本語版. 日本動物分類学関連学会連合, 札 幌

Fukami H, Hatta M, Omori M (2000) Phylogenetic relationships in the coral family Acroporidae, reassessed by inference from mitochondrial genes. Zool Sci 17: 689-696

Fukami H, Chen CA, Budd AF, Collins A, Wallace C, Chuang Y-Y, Chen C, Dai C-F, Iwao K, Sheppard C, Knowlton N (2008) Mitochondrial and nuclear genes suggest that stony corals are monophyletic but most families of stony corals are not (order Scleractinia, class Anthozoa, phylum Cnidaria). PLoS ONE 3: e3222

Gardiner JS (1898) On the perforate corals collected by the author in the South Pacific. Proc Zool Soc Lond 1898: 257-276

廣瀬慎美子・目崎拓真・野澤洋耕・磯村尚子 (2010) ミーティングレポート：日本産イシサンゴ類の有 性生殖について語ろう。日本サンゴ礁学会誌 12 : $59-64$

International Commission on Zoological Nomenclature (ICZN) (1999) International Code of Zoological Nomenclature Fourth Edition. The International Trust for Zoological Nomenclature 1999, The Natural History Museum, London

Kojis BL (1986a) Sexual reproduction in Acropora (Isopora) species (Coelenterata: Scleractinia). I. A. cuneata and $A$. palifera on Heron Island reef, Great Barrier Reef. Mar Biol 91: 291-309

Kojis BL (1986b) Sexual reproduction in Acropora (Isopora) (Coelenterata: Scleractinia). II. Latitudinal variation in A. palifera from the Great Barrier Reef and Papua New Guinea. Mar Biol 91: 311-318 
Lamarck JBPA de M de (1816) Histoire naturelle des animaux sans vertebres. Paris 2: 1-568

西平守孝・Veron JEN (1995) 日本の造礁サンゴ類. 海游舎, 東京

野村恵一（2009）和歌山県串本海域における近年の サンゴ群集変化. 日本サンゴ礁学会誌 11: 39-49

Okubo N, Isomura N, Motokawa T, Hidaka M (2007) Possible self-fertilization in the brooding coral Acropora (Isopora) brueggemanni. Zool Sci 24: $277-280$

Randall RH (1981) Morphologic diversity in the scleractinian genus Acropora. Proc $4^{\text {th }}$ Int Coral Reef Symp, Manila 2: 157-164

Studer T (1878) Zweite abtheilung der Anthozoa polyactinia welche während der Reise S.M.S. Corvette Gazelle um die Erde gesammelt wurden. Monatsber Dtsch Akad Wiss Berlin 25: 524-550

van Oppen MJH, McDonald BJ, Willis BL, Miller DJ (2001) The evolutionary history of the coral genus Acropora (Scleractinia, Cnidaria) based on a mitochondrial and a nuclear marker: reticulation, incomplete lineage sorting or morphological convergence? Mol Biol Evol 18: 1315-1329

Veron JEN (2000) Corals of the world. Aust Inst Mar Sci, Townsville

Veron, JEN, Wallace CC (1984) Scleractinia of Eastern Australia V, Family Acroporidae. Aust Inst Mar Sci Monogr Ser 6: 1-485
Villanueva RD, Baria MVB, dela Cruz DW, Dizon RM (2011) Diel timing of planulation and larval settlement in the coral Isopora cuneata (Scleractinia: Acroporidae). Hydrobiologia 673: 273-279

Wallace CC (1985) Reproduction, recruitment and fragmentation in nine sympatric species of the coral genus Acropora. Mar Biol 88: 217-233

Wallace CC (1997) New species and new records of recently named species of the coral genus Acropora (Scleractinia: Astrocoeniina: Acroporidae) from Indonesia. Zool J Linn Soc 120: 27-50

Wallace CC (1999) Staghorn corals of the world: A revision of the coral genus Acropora (Scleractinia; Astrocoeniina; Acroporidae) worldwide, with emphasis on morphology, phylogeny and biogeography. CSIRO Publishing, Melbourne

Wallace CC, Chen CA, Fukami H, Muir P (2007) Recognition of separate genera within the large coral genus Acropora based on new morphological, reproductive and genetic evidence from $A$. togianensis, and elevation of the subgenus Isopora Suder, 1878 to genus (Scleractinia: Astrocoeniidae; Acroporidae). Coral Reefs 26: 231-239

2012 年 8 月 10 日 受領 2013 年 3 月 13 日 受理

(C) 日本サンゴ礁学会 
Commentary

\title{
Taxonomy and ecology of the genus Isopora (Acroporidae, Scleractinia)
}

\section{Hironobu FUKAMI ${ }^{1}$, Naoko ISOMURA ${ }^{2, *}$, Kenji IWAO ${ }^{3}$, and Hiroyuki TACHIKAWA ${ }^{4}$}

\author{
${ }^{1}$ Department of Marine Biology and Environmental Science, Faculty of Agriculture, University of Miyazaki, \\ 1-1 Gakuen-kibanadai Nishi, Miyazaki 889-2192, Japan \\ ${ }^{2}$ Department of Bioresources Engineering, Okinawa National College of Technology, 905 Henoko, Nago-City, \\ Okinawa 905-2192, Japan \\ ${ }^{3}$ Akajima Marine Science Laboratory, 179 Aka, Zamamison, Okinawa 901-3311 Japan \\ ${ }^{4}$ Natural History Museum and Institute, Chiba, 955-2 Aoba-cho, Chuo-ku, Chiba 260-8682, Japan \\ * Corresponding author: N. Isomura \\ E-mail: iso@okinawa-ct.ac.jp \\ Communicated by Masayuki Hatta
}

\begin{abstract}
The family Acroporidae (Scleractinia) formerly contained four genera such as Acropora, Anacropora, Astreopora, and Montipora (for examples, Veron and Wallace 1984; Nishihira and Veron 1995; Veron 2000). Recently, Wallace et al. (2007) has elevated the subgenus Isopora, which was one of two subgenera in the genus Acropora, to genus, based on the morphological, ecological and molecular data. Then number of genera in the Acroporidae becomes five. Nevertheless, in Japan, this fact is not generally known and the genus name Acropora is still applied to the species, which should belong to the new genus Isopora. In this paper, to make public the name of the genus Isopora, and to propose the Japanese name of this genus, we summarize the morphological and ecological characters of this genus. The contents of this paper are mainly based on Wallace et al. (2007). In addition, we show morphological and ecological data from samples of Isopora that were collected in Japan. On the basis of the International Code of Zoological Nomenclature (Art. 69.2.2), we note that type species of Isopora is Madrepora labrosa Dana, 1846, not Astrea palifera Lamarck, 1816.
\end{abstract}

Keywords: Scleractinia, Isopora, skeletal morphology, Japanese name, subgenus, Japanese samples, type species

Received: 10 August 2012/Accepted: 13 March 2013

(C) Japanese Coral Reef Society 